\title{
The literary «ekphrasis» of Castel Nuovo: a contribution to value the cultural identity of the ideal city government, promoted by aristocratic courts and civil administrations in the XIV century
}

\author{
CIPOLLA Sara
}

\author{
Centro Universitario Cattolico, \\ via Leonardo da Vinci 37a, 87040, Castrolibero (CS), Italy \\ cipolla.sara@libero.it
}

Keywords: literary ekphrasis, Neuf Preux, allegorical literature, Worldly Glory, list of heroes

\begin{abstract}
The research work concerns the development in the Italian literature of the French theme of Neuf Preux, and Particularly Took into account a crown of sonnets of nine famous men linked to an alleged cycle of paintings attributed to Giotto's in the palace of Castel Nuovo in Naples. The survey highlighted how in medieval Italian literature, beyond the more or less explicit recovery of the French literary tradition, occupies a prominent place the function that these poems take in the view of the literature of the time. The survey actually shows the two faces of the series of famous heroes, which on one hand is the mouthpiece of the political ideals and civil inspired by the courteous and Roman antiquities, on the other hand appears to be ripe fruit of a didactic poem in which the adherence to the motto of ut pictura poesis become as a kind of surface projection of images.
\end{abstract}

In the Italian literary scene (I refer in particular to the literature of allegorical and moral genre) at the turn of the thirteenth and fourteenth century we are witnessing a process of intertextual contamination between motifs and genres typically peninsular and topical elements of Romance origin. The reason for this mixture is to be found in the social and political changes that characterize this era: the increasingly decisive affirmation of municipal oligarchies in union with the presence of an aristocratic class strongly tied to the traditions and customs of the French court. Against the backdrop of the political scene of the thirteenth century there are important literary documents heavily debtors to the traditional romance topoi (most of them coming by courteous and chivalrous literature). One issue in particular had considerable success in the Italian literary and artistic scene: I am referring to the topos of the Neuf Preux, also called "Nine Worthies": a motif derived in the canonical form by the Voeux du Paon of Jacques de Loguyon (1312), that presents a gallery of nine heroes, three of which are pagans (Hector, Alexander and Caesar), three Jews (Joshua, David and Judas Maccabeus) and three Christians (Arthur, Charlemagne and Godfrey of Bouillon). The motif, due to the kind of literary allegorical production, boasts, among eleventh and fourteenth centuries, an extensive tradition in art and Transalpine literature: literary and artistic testimonies of the series are found not only in France but also in England, Scotland, Spain and Germany [1,2,3,4]. The reason for such a poetic and iconographic luck binds mainly to the communicative scope of the topic, to the ability to summarize, in the presentation of valiant men, the temporal virtues of the Buon Governo, which, even in the late fourteenth century, were identified with the chivalrous and courtly values. So we can appreciate the special attention showed by nobility and by municipal oligarchies of the time to realize such representations, often accompanied by more or less long inscriptions in verse, in the mansions and municipal boardrooms. I'm thinking about the pictures of Gentile da Fabriano in Palazzo Trinci in Foligno, accompanied by a rich array of epigrams, which introduce the visitor to the observation of the paintings shown in hall; also the series of Nine heroes and heroines in the baronial hall of the Castel of Manta in Cuneo, painted between 1416 and 1443 during the rule of the Valerano Burdo, is an important testimony of this kind of representations. In particular, within the pro-French court of Naples lie two testimonies valuable for the reconstruction of the development of the Italian theme of the Nove Prodi: I refer to the lost frescoes cycle of nine illustrious men in Castel Nuovo (Naples), painted, according to sources [5,6,7,8,9], 
from Giotto during his stay in Naples (1329-1333), and the Crown of sonnets attributed to Giovanni da Firenze, who describes its contents [10,11]. These nine texts do not actually represent the only evidence of the fortune Italian French theme. The investigations conducted so far on the presence of the topos of the Preux in medieval Italian literature have shown a certain interest about the argument, absolutely not least, of the best known literary man of the time. Just to cite a few examples, the complete sequence of the nine heroes of tradition is present in the novel CXXV, 2 of Franco Sacchetti's Il trecentonovelle and in the Quadriregio of Federico Frezzi (IV, VII 32-123), a variation on the theme figure in the Dante's song of Cacciaguida (Par. XVIII 37-51), while more or less orthodox sequences of heroes are in the works of Boccaccio (De Casibus virorum illustrium and Amorosa Visione) and Petrarch (Trionfi e De viris illustribus).

Both Dante, Petrarch and Boccaccio in fact voluntarily modify the canonical series of heroes, through the use of poétique de la list ouverte, not numerically defined and ready to accept the universality of mankind, for administrative extol the virtues of the Buon Governo [12]. The key common to all the works, functional to understand the grafts game between literary and artistic reasons, is made by combination of the couple of words Fama / Virtue [12,13]. It is well known that both the De viris and the Triumphus Fame have enjoyed, particularly during the Renaissance, a remarkable iconographic fortune, and indeed, it seems that in the encounter between the triumphal subject and the parade of heroes, at the turn of the fourteenth and fifteenth century, are frequently situated various iconographic projects: this might be the case, as argued Marcello Ciccuto [14], of the alleged cycle of famous Men of Castel Nuovo, painted by Giotto (according to the tradition), and described in the nine sonnets attributed to the Florentine Malizia Barattone, that, in parallel to the Worldly Glory, painted by the Florentine painter in the palace of Azzone Visconti in Milan (also this fresco, like the aforementioned cycle of Castel Nuovo, has never been found, although there are several literary and figurative testimonies - except for the supposed allusion of Boccaccio in Amorosa Visione (B) IV 10-21 - which would ensure the execution. The first literary source for the reference is to the Chronica of Galvano Fiamma [15], a chronic of the city of Milan, in which the author describes the palace of Azzone Visconti and mentions a fresco of vainglory; Giovanni Villani, then, in his Cronica XII, XII, 15 [16], states that Giotto was in the service of Azzone Visconti, and Lorenzo Ghiberti in his Commentari [9] refers to the realization of a Worldly Glory by Giotto. The testimony of Ghiberti, evoked by Giorgio Vasari [8] in the sixteenth century, who however recognizes the fresco of Worldly Glory in a painting of the same subject in the Oratory of Annunziata in Padua (see vol. I, p. 400) was reconsidered by Creighton Gilbert [17], who believes that the attribution to Giotto's vainglory Visconti is fully valid. As far as the iconography of the Triumph of Fame, Gilbert still recovers the two images of the illuminated frontispiece of Petrarch's De viris, containing the representation of the Triumphus Fame: the manuscripts Par. Lat. $6069 \mathrm{f}$ and 6069 I, guarded in the National Library of Paris, to whom the painting was certainly closer), introduces the following of illustrious men in the traditional iconography of the Triumph of Fame. To be precise Ciccuto said that the source of the iconographic motif of Giotto is in the Neapolitan court of Robert of Anjou, and in a later moment was replicated in the north of the island by the same painter: so the motif was «costituito forse subito [...] sull'intenzionale, e rivoluzionaria, sovrapposizione del motivo della Fama alla ieratica sequenza dei Prodi che i sonetti del Barattone ci ha conservato» [14] (see on p. 358). The presence of Giotto in the Neapolitan art scene in the second half of the fourteenth century, together with the aforementioned literary tradition, that wants Giotto to head of the cycle of Castel Nuovo, has always convinced scholars, who have analyzed the relationship between literary text and pictorial ones in the nine sonnets of illustrious men, about Giotto's authorship of the images that evoke these compositions [17,18,19,20,21,22]. At this point I think that is very important to study the link between the cycle of Florentine sonnets and the lost iconographic tradition, whom inevitably binds, because of the specific and non-isolated references about the paintings that we can found in the manuscripts: already starting from the starting rubrica that introduces the sonnets in the Ms. Laurentiano Redi 184 of the Laurentian Library, c. 124, there is a clear reminder of the paintings («Sonetti composti per [...] il quale essendo nella sala di Re Ruberto a Napoli vide dipinti questi famosi uomini e lui fe' a ciascuno il suo sonetto come qui 
appresso»), also reiterated in sonnet of Samson, vv. 1-2: «Voi che mirando andate greci ebrei / famosi antichi per la sala bella».

As we known, medieval didactic literature frequently used elegant digressions (ž $\kappa \phi \rho \alpha \sigma l \varsigma)$ modulated on the contemporary imaginary figurative; in this case we can hazard a most illustrious and less generic comparison between the ekphrasis of the sonnets and a literary model certainly known in the Neapolitan and Florentine environment: Boccaccio's Amorosa Visione. An interesting perspective is offered by numerous studies on the presumed influence of the lost fresco of Worldly Glory of Giotto (or Vainglory in triumph with illustrious men), painted according to the sources by the illustrious Florentine in the hall of Azzone Visconti's Palace in Milan (1335), in the allegorical structure of the procession of heroes described by Boccaccio in Amorosa Visione. Gilbert [17], in particular, believes that Boccaccio was precisely inspired by from the Milanese painting of Giotto for the construction of the Triumph of the Glory in the Amorosa Visione (see p. 140). Unlike him Ciccuto [14] speculates that Boccaccio was inspired by the frescoes of Giotto in Castel Nuovo, imagining that the iconographic structure of Neapolitan hall presented itself, not so much as a parade of ancient heroes, but rather as a Worldly Glory in triumph with a procession of famous men, exactly like that of Milan: commensurate, therefore, with the testimony of the Amorosa Visione (see pp. 347-348). Looking to the source, in the fourth canto of the Amorosa Visione, Boccaccio describes the entrance of the protagonist in a room, located inside an imaginary palace, where he saw a portrait of Worldly Glory, and with her «molte genti / sovra un erboso e ben fiorito prato, / alcuni più e alcun meno eccellenti» $(A V(B)$ IV 31-33). If it is reasonable to assume that in the construction of ekphrasis Boccaccio has drawn from the conspicuou literary tradition and - why not? - also from the figurative tradition of Preux, together with the motif of Triumphus Famae, is not certain that He refers to a real painting by Giotto. In support of this thesis I remember you how Boccaccio on several occasions praised the Florentine painter: «avendo egli quell'arte ritornata in luce, che molti secoli sotto gli errori d'alcuni, che più a dilettar gli occhi degl'ignoranti che a compiacere allo 'ntelletto de' savi dipignendo, era stata sepulta, meritamente una delle luci della fiorentina gloria dir si puote» (Decameron VI 5, 5-7). Giotto is also mentioned in Genealogie XIV 6: «Sed deprecor, si Praxiteles aut Phydias, scultura doctissimi, impudicum sculpserint Pryapum in Yolem noctem tendentem potius quam spectabilem honestate Dianam, aut si pingat Apelles, seu noster Ioctus, quo suo evo non fuit Apelles superior, Martem seu Veneri inmiscentem potius quam Iovem diis ex trono iura prebentem, has artes damnandas fore dicemus? Solidissimus esset fateri!», and in the Zibaldone "Magliabechiano» (Florence, National Library, ms. B. R. 50, c. 232v) compared with the illustrious men. Therefore it isn't strange that Boccaccio had chosen Giotto as the ideal painter of that hall. In additional to this, the pictorial suggestions present in the Amorosa Visione, as also in the Decameron and in the Filocolo, in which there is also present the motif of room decorated with works of art (Fil. 32,2), typical of the literary ekphrasis, are included in the wider landscape of the fourteenth-century figurative art (already largely outlined in the studies of Lucia Battaglia Ricci [23]), and we can't reduce it to a single pictorial document, moreover uncertain. According to some scholars, in effect, the literary documents, that relate to the award to Giotto of the frescoes in the Sala Maior of Castel Nuovo, are not considered so reliable: Giuseppe De Blasiis [24] ruled out the authorship of Giotto, just because it is based on the testimony initial Ghiberti [9], in his opinion unreliable. Also Giovanni Previtali [25] was skeptical, because he identified the only testimony of Giotto's Neapolitan cycle which can be defined documented: I refer to the fragments of the fresco (representing the potraits of saints and illustrious men) painted in the Palatine Chapel of S. Barbara in Castel Nuovo (see p. 122); this testimony therefore, strictly speaking, would be the only presence of a cycle of Illustrious men in Castel Nuovo. After him Francesco Aceto [26] has again questioned the creation by the Tuscan artist of the frescoes in the Sala Maior based on the analysis of the documents certifying the Neapolitan activity of the Giotto, in which: «manca - according to the scholar - qualsiasi riferimento sia alle pitture di Santa Chiara sia agli 'Uomini famosi' dipinti in Castelnuovo» (see p. 58). Aceto also reminds us that there is no documents that guarantee that Ghiberti really visited Naples, while it is recognized by all scholars that to the basis of all the evidences there is the text of the Commentari [9]. According to this it 
could be argued that Ghiberti had just heard the news of the frescoes from the book that accompanies the crown of sonnets in Ms. Laur. Redi 184 of the Laurentian Library, c. 124. Therefore if we can rigorously talk about «interespressività» [27] in Boccaccio's literary works, that are full of contemporary figurative culture, and make up a clear example of that «visibile parlare» (Pg. X 95) [28,29] gleaned by Dante's model, in which the image viewing is a «metafora della finzione narrativa» [30] (see p. 329), I believe that even the Neapolitans sonnets are attributable to the same poetica della visualità, which clearly expresses the deep connection between text and image so evident in medieval culture [31]. The previous literary text represented by Amorosa Visione lead us to believe that, following the example of Boccaccio, even the crown of Castel Nuovo could constitute an autonomous textual ekphrasis, not an illustrative corpus and less than ever tied to an epigrammatic description (like those descriptions inserted at the bottom of the painted figures), as well as happens in the figurative cycles of illustrious men [32], but we have to think about it as effigies loquitur, reliable evidence of «un parlare che non si percepisce con l'udito, ma con la vista» [33].

In this regard, I would like to highlight certain formal and stylistic choices of the author of the sonnets. Pasquale Stoppelli has well recognized in the opening expression Io son, found in the sonnets also in the variant Io fui, that shows itself functional to the character who presents himself and illustrates his exploits, a link with the literary genre of the pomposity sonnets [10], but in reality it is present in different types of allegorical and didactical literary texts: for example the religious laude, the erotic ballads and popular songs, already mentioned, the political songs and pomposity sonnets of vices and virtues or the sonnets of illustrious men and women (see what said Claudio Ciociola [27], on p. 14 and pp. 38-42). This expression, much akin to the formula of Ubi sunt, typical of the writings of Preux, which introduces the theme of death and the vanity of worldly glory $[1,2]$, is an intrinsic characteristic of the literary description of works of art. Together with the presentational expression, in the texts recur the formula of the $\dot{\alpha} \pi \sigma \sigma \tau \rho o \phi \dot{\eta}$ addressed to the reader (3. [Achille], v. 1: «Lettore, io fui '1 magnifico d'Acchille»; 8. [Alessandro], v. 15: «Lettor, se pigro se', mio essempro tolli»; 5. [Sansone], v. 1: «Voi che mirando andate i greci 'ebrei») that, connected with the wide use of deictic elements (note the use of «questa», present in 1. [Salomone], v. 1; 2. [Ettore], v. 9; 3. [Achille], vv. 9 e 13; 6. [Paride], v. 13; «esta», in 5. [Sansone], v. 6; «la quale», in 3. [Achille], v. 10; 5. [Sansone], v. 7; 2. [Ettore], v. 9; 3. [Achille], v. 12; «Il qual», in 4. [Enea], v. 5; «il quale» in 7. [Ercole], v. 2; «di cui», in 1. [Salomone], v. 2; 2. [Ettore], v. 11), adverbial complements of location (see for example the use of «qui» in 2. [Ettore], v. 2; 4. [Enea], v. 1; 6. [Paride], v. 2; "Quivi», in 6. [Paride], v. 9; 8. [Achille], v. 12) and words denoting the vision (2. [Ettore], v. 9: «sì fiso mi mira»; 3. [Achille], v. 10: «io miro»; 5. [Sansone], vv. 1-3: «mirando [...] mirate me»; 8. [Alessandro], v. 1: «mostro»; 4. [Enea], v. 1: «qui figurato scorto»), remind us that the Neapolitan poems can be ascribed to the genre of literary ekphrasis, common to writers such as Dante and Boccaccio [28,31]. In the bargain we can note the additional use, though not continuous, of hypotýpōsis, that overlooking in some very vivid descriptions and rich in detail (I am referring to the use of descriptive details concerning the actions conducted by these heroes and their personal stories: for example in the sonnet of Samson, v. 11, the description of the loss of his force due to Delilah, who cut his hair, is particularly lively, also thanks to the almost impressionistic

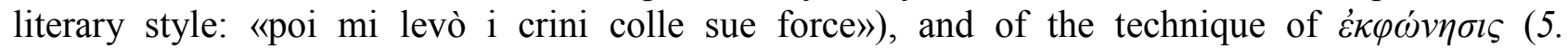
[Sansone], v. 15: «fin ch'io non dissi: - Muoia Sanson co' suoi -»).

The hypothesis that we are speaking about pure narrative poetry, tied to a narration through pictures, effective stylistic expedient of the didactic literature, in my opinion, does not rule out a relationship with the environment of Neapolitan court of Robert of Anjou, yet imbued with French culture and rich of literary suggestions taken from Boccaccio's texts. Following a research conducted this year on the poetry of the Kingdom of Naples in Angevin period, I found a literary testimony of the French Preux, which shows that the motive was known in the literature of the second half of the fourteenth century and was used in its ethical and civil meaning. I refer to the Sonetto de re Karlo terzo, facto per misser Paulo de la Corona, attributed to Paolo dell'Aquila, a poet of which very little is known [32]. The sonnet, written for the death of King Charles III and 
dated on 1386 [33], shows a large group of illustrious men, despite that were celebrated for virtue and glory of their actions, «né furon mai alcuni d'onor sì degni / quanto colui la cui gran voce e fama / vive beata nei celesti regni» (Sonetto de re Karlo terzo, vv. 9-11). Among these heroes are present Hector, Caesar, Alexander, Arthur, Charlemagne and Judas Maccabeus, belonging to the French tradition of Preux, that appear alongside other valiant men of Carolingian epic (Troilus and Orlando), of Roman history (Hannibal and Tarquinio Prisco), of late antiquity (Constantine), of medieval period (Saladin) and of mythology (Theseus, Hercules). Another time we can see that the use of the list is not exactly canon, but more oriented to the universality of the exemplary theme, although appears as an explicitly reminder to the procession of French Preux, included in its ethical and civic function. Moreover, the choice of describing a procession of illustrious men from different cultural traditions accords well with the desire to celebrate the universality of the political power of King Charles III, and is linked to the tendency of the courts of Europe and of Italian municipalities to use some literary themes of didactic origin with the specific intent to illustrate the positive effects of "Good Government" and the regent's administrative virtues.

Finally, the documented presence in the French tradition of the nine brave men of Neapolitan sonnets, also corroborated by the discovery in the Library of Cassino of a manuscript, containing Les Voeux du Paon written by Jacques de Longuyon (1312) [34], the text from which originated the literary genre, it certainly helps to better delineate the network of historical and literary documents that lie behind the creation of the crown of sonnets in Florence. This doesn't exclude, however, that these texts are heavily indebted to a literary tradition far more impressive and full of testimonials, which is precisely the literary ekphrasis.

\section{Acknowledgements}

This research was realized with economic support of Centro Universitario Cattolico, that I want to thanks for this opportunity.

\section{References}

[1] H. Schröeder, Der Topos der Nine Worthies in Literatur und Bildender Kunst, Göttingen, Vandenhoeck \& Reprecht 1971.

[2] K. J. Höltgen, Die «Nine Worthies», «Anglia», LXXVII (1959), pp. 279-309.

[3] R. S. Loomis, Verses on the Nine Worthies, «Modern Philology», XV (1917), 4, pp. 19-27.

[4] P. Meyer, Les Neuf Preux, «Bulletin de la Société des Anciens Textes Français», IX (1883), pp. 45-54.

[5] P. L. De Castris, Giotto a Castel Nuovo, Napoli, Electa 2006, p. 217, n. 2.

[6] C. De Fabriczy, Il codice dell'Anonimo Gaddiano della Biblioteca Nazionale di Firenze, in «Archivio Storico Italiano», S. V. T. XII (1893), p. 36.

[7] G. B. Gelli, Venti vite di artisti, Ms. Strozziano 952, 1550, Florence, Laurentian Library.

[8] G. Vasari, Le Vite de' più eccellenti pittori scultori ed architettori scritte da Giorgio Vasari pittore aretino, in: Le opere di Giorgio Vasari, edited by G. Milanesi, Firenze, Sansoni 1973.

[9] L. Ghiberti, Commentari II 3, in: L. Ghiberti, I Commentari, edited by O. Morisani, Napoli, Ricciardi 1957.

[10] P. Stoppelli, Malizia Barattone: (Giovanni da Firenze) autore del Pecorone, «Filologia e critica», 1 (1977), pp. 1-34.

[11] P. Stoppelli, I sonetti di Giovanni da Firenze (Malizia Barattone), «F. M. Annali dell'Istituto di Filologia Moderna dell’Università di Roma», 1 (1977), pp. 189-221.

[12] S. Cipolla, L'arte del "buon governo": l'esaltazione dei valori civili nell'arte e nella letteratura fra Tre e Quattrocento, in: Atti del XV Congresso Nazionale dell'Associazione degli Italianisti Italiani (ADI), Torino, 14-17 settembre 2011, edited by C. Allasia, M.. Masoero, L. Nay, Alessandria, Edizioni dell'Orso, 2012, CD-ROM.

[13] J. Cerquiglini-Toulet, «Fama» et les Preux: nom et renom à la fin du Moyen Âge, «Médievalés», 24 (1993), pp. 35-44. 
[14] M. Ciccuto, «Trionfi» e «Uomini illustri» fra Roberto e Renato d'Angiò, «Studi sul Boccaccio», XVII (1988), pp. 343-402.

[15] G. Fiamma, Gualvanei de la Flamma ordinis praedicatorum Opusculum de rebus gestis ab Azone, Luchino et Johanne vicecomitibus ab anno 1328 usque ad annum 1342, edited by C. Castiglioni, in: Rerum Italicarum Scriptores, edited by L. A. Muratori, t. XII, vol. IV, Bologna, Zanichelli, 1938.

[16] G. Villani, Cronica, in: G. Villani, Cronica, con le continuazioni di Matteo e Filippo, introduction and notes by G. Aquilecchia, Torino, Einaudi 1979.

[17] C. E. Ghilbert, Poets seeing artists' work. Instances in the Italian Renaissance, Firenze, Olschki 1991.

[18] P. L. Leone de Castris, Giotto a Napoli, Napoli, Electa Napoli, 2006, pp. 217-233.

[19] F. Bologna, I pittori alla corte angioina di Napoli, 1266-1414, e un riesame dell'arte nell'età fridericiana, Roma, U. Bozzi 1969, pp. 219-223.

[20] R. Filangeri, Castel Nuovo reggia angioina ed aragonese di Napoli, Napoli, L'arte tipografica 1964, pp. 8-9.

[21] A. Altamura, Affreschi e sonetti del Trecento in Castelnuovo, «Il Fuidoro», I (1954), pp. 174175.

[22] M. M. Donato, Gli eroi romani tra storia ed «exemplum». I primi cicli umanistici di Uomini Famosi, in: Memoria dell'antico nella storia dell'arte italiana, edited by S. Settis, vol. II, I generi $i$ e temi ritrovati, Torino, Einaudi 1985, p. 111-152.

[23] L. Battaglia Ricci, Parole e immagini nella letteratura italiana medievale: materiali e problemi, Roma, GEI 1994

[24] G. De Blasiis, Immagini di uomini famosi in una sala di Castelnuovo attribuite a Giotto, «Napoli Nobilissima», IX (1900), pp. 65-67.

[25] G. Previtali, Giotto e la sua Bottega, Milano, Fabbri 1967.

[26] F. Aceto, Pittori e documenti della Napoli angioina: aggiunte ed espunsioni, «Prospettiva», 67 (1992), pp. 33-65.

[27] W. Wehle, "Venus magistra vitae": sull'antropologia iconografica del Decameron, in: Autori e lettori di Boccaccio, Atti del Convegno internazionale di Certaldo (20-22 settembre 2001), edited by M. Picone, Firenze, Franco Cesati 2002, p. 345.

[28] G. Pozzi, Dall'orlo del "visibile parlare", in: «Visibile parlare». Le scritture esposte nei volgari italiani dal Medioevo al Rinascimento, Napoli, Edizioni Scientifiche Italiane 1997, pp. 15-41.

[29] C. Ciociola, «Visibile parlare»: agenda, Cassino, Università degli studi, 1992.

[30] R. Stillers, L'«Amorosa Visione» e la poetica della visualità, in: Atti del Convegno internazionale di Certaldo (20-22 settembre 2001), edited by M. Picone, Cesati 2002, pp. 327-342.

[31] C. Ghilbert, La devozione di Giovanni Boccaccio per gli artisti e l'arte, in: Boccaccio Visualizzato. Narrare per parole e per immagini fra Medioevo e Rinascimento, edited by V. Branca, Torino, Einaudi 1999, vol. I, pp. 146-147.

[32] H. Wenzel, Hören und Sehen - Schrift und Bild. Kultur und Gedächtins im Mittelalter, Monaco, Bech 1995, pp. 338 sgg..

[33] A. M. Chiavacci Leonardi, Comment to X 94, in: D. Alighieri, Purgatorio, edited by A. M. Chiavacci Leonardi, Milano, Mondadori 1997, p. 307.

[34] R. Guerrini, «Cernere vultus». La Galleria degli Eroi di Virgilio e la tradizione ecfrastica nella Sala degli Imperatori di Palazzo Trinci a Foligno, in: Nuovi studi sulla pittura Tardogotica, edited by A. Caleca e B. Toscano, Foligno, Sillabe 2009, pp. 59-60.

[35] F. Torraca, Lirici napoletani del secolo XIV, in: F. Torraca, Studi di storia letteraria napoletana, Livorno, Vigo editore 1884, p. 247.

[36] R. Coluccia, Tradizioni auliche e popolari nella poesia del Regno di Napoli in età angioina, «Medioevo Romanzo», 2 (1975), p. 100.

[37] G. Brunetti, Un testimone dei "Voeux du Paon" in Italia, «Studi mediolatini e volgari», 46 (2000), pp. 7-34. 